\title{
Huntington's Disease: Recent Advances in Diagnosis and Management
}

\author{
Sarah Furtado and Oksana Suchowersky
}

\begin{abstract}
Huntington's Disease (HD) is a progressive degenerative disorder of the central nervous system inherited as an autosomal dominant trait. Clinically, the disorder is characterized by choreoathetosis (with age of onset typically in the late thirties or early forties) and neuropsychiatric disturbance. The striatum is particularly vulnerable to the degenerative disease process, with selective loss of medium spiny neurons and decreased levels of associated neurotransmitters, including substance $P$, GABA, met-enkephalin and dynorphin. Although the underlying pathophysiology is unknown, recent theories concerning pathogenesis have involved mitochondrial abnormalities and excitotoxin-mediated damage. The gene for HD has recently been discovered and characterized as an unstable CAG trinucleotide repeat sequence on the short arm of chromosome 4 (now known as IT15). The direct test now available for the HD gene has facilitated disease diagnosis, particularly for those with unclear family history or chorea of uncertain origin; presymptomatic testing is also available. Management of affected individuals is unsatisfactory as only symptomatic control is available. However, as the effect of the genetic abnormality may soon be known, specific treatment of the disorder may become available in the near future.
\end{abstract}

RÉSUMÉ: Maladie de Huntington: progrès récents dans le diagnostic et le traitement. La maladie de Huntington $(\mathrm{MH})$ est une maladie dégénérative progressive du système nerveux central dont l'hérédité est autosomale dominante. La maladie se caractérise au point de vue clinique par de la choréo-athétose et des troubles neuropsychiatriques, dont l'âge de début est habituellement dans la trentaine avancée ou au début de la quarantaine. Le striatum est particulièrement vulnérable au processus dégénératif: perte sélective des neurones épineux de taille moyenne et niveaux abaissés de leurs neurotransmetteurs dont la substance $P$, le GABA, la met-enképhaline et la dynorphine. Bien que la pathophysiologie sous-jacente soit inconnue, des théories récentes sur la pathogenèse de la maladie proposent que des anomalies mitochondriales et des dommages excitotoxiques sont en cause. Le gène de la maladie de Huntington a été découvert récemment et l'anomalie responsable de la maladie a été caractérisée. Il s'agit d'une séquence répétitive instable de trinucléotides CAG localisée sur le bras court du chromosome 4 (nommée IT15). Le test direct, qui est maintenant disponible pour identifier le gène de la $\mathrm{MH}$, a facilité le diagnostic de la maladie, surtout pour les patients dont l'histoire familiale est obscure ou dont l'étiologie de la chorée est incertaine. Le test présymptomatique est également disponible. On ne peut offrir qu'un traitement symptomatique aux individus atteints, ce qui demeure insatisfaisant. Cependant, les conséquences de l'anomalie génétique seront probablement connues bientôt et un traitement spécifique de la maladie pourrait être disponible dans un avenir rapproché.

Can. J. Neurol. Sci. 1995; 22: 5-12

Huntington's Disease (HD), an autosomal dominant neurodegenerative disorder was first described by the American physician George Huntington in 1872 . Huntington had first observed the disease in his father's medical practice; his grandfather, also a physician, had noted the disorder. Thus, the seminal paper that the twenty-two year old George Huntington presented in the late nineteenth century was based on the longitudinal observations of three generations of physicians of their affected patients in Long Island, New York, a cumulation of some 78 years of remarkable experience. HD was recognized as a distinct entity for about 50 years prior to Huntington's description and has likely existed for many centuries. ${ }^{1-3}$

The prevalence of HD varies from five to eight per 100,000 in Europe and North America, ${ }^{4,5}$ making it as common as myotonic dystrophy or Duchenne's muscular dystrophy. In North America, HD is primarily present in families of European descent and is rare in individuals of Japanese or African origin. It remains a significant cause of morbidity with wide reaching consequences, not only for the affected individuals, but also for their families.

From the Department of Clinical Neurosciences, Faculty of Medicine, The University of Calgary, Calgary.

RECEIVED MARCH 28, 1994. ACCEPTED IN FINAL FORM JULY 8, 1994

Reprint requests to: Dr. O Suchowersky, Department of Clinical Neurosciences, The University of Calgary, 1403 - 29 Street N.W., Calgary, Alberta, Canada T2N 2T9 


\section{Clinical Features}

The average age of onset of HD, defined by the onset of the motor disorder, is typically in the late thirties and forties. However, the disease has been reported in children as young as four years of age, as well as individuals in their seventies. ${ }^{3}$ The age of onset will vary among families, with some showing a consistently older age of onset than others. However, it should be recognized that there can be a wide range of age of onset among individuals from the same family. Sex of the transmitting parent plays an important role: children of an affected father may have a younger age of onset than the children of an affected mother. ${ }^{6-8}$

Chorea is the most characteristic feature of HD, and refers to brief, irregular, jerky movements which affect the face and limbs. Initially, these movements begin as a complaint of restlessness in the face and extremities, and at this stage, the chorea may be incorporated into purposeful movements. Slowly, the chorea becomes more florid, involving the limbs and body axis and interfering with simple tasks of coordination. Athetosis and dystonia may be superimposed on the chorea, particularly in advanced $\mathrm{HD}$, lending the motor disorder a writhing quality. ${ }^{9}, 10$ Many patients are unaware of the chorea, particularly in the early stages, and deny that they are affected. This lack of patient awareness is in contradistinction to other hyperkinesias such as tics or myoclonus.

Hypotonia, mild hyper-reflexia, buccolingual apraxia and difficulty with repetitive fine finger movements are commonly associated with chorea in the early stages. Gait may be affected, resulting in a wide-based staggering gait with impaired stride length, sometimes referred to as Huntington's ataxia." As the disorder progresses, individuals develop bradykinesia, rigidity, spasticity, and an upgoing plantar reflex. Other late abnormalities include dysarthria, dysphagia and urinary incontinence. Eventually, the chorea attenuates and bradykinesia or spasticity is prominent in the terminal stage. ${ }^{9-15}$

Eye movement abnormalities are frequently present, even in early stages. These include difficulty in initiating voluntary saccades, inability to suppress head movements or blinking during voluntary eye movements, and gaze fixation abnormalities. ${ }^{14}$ An inability to suppress saccades to external stimuli has also been noted. ${ }^{16,17}$

Cachexia is almost always observed in HD, occurring even when a high calorie diet is maintained. This suggests an associated hypermetabolic state. ${ }^{18}$

Although the majority of patients present with neurological symptoms, psychiatric manifestations occur as the presenting symptom in up to one-third of patients, and can occasionally precede the onset of the motor disorder by as much as $10-15$ years. After disease diagnosis (based on chorea onset), family members frequently report that for some years prior to diagnosis, the patient no longer seemed like himself, was easily irritable, suspicious and impulsive. ${ }^{19-21}$ Personality change, depression, anti-social behaviour and delusional thinking can occur resulting in initial misdiagnosis of a psychiatric disorder such as schizophrenia or manic-depressive illness. Sexual disorders, including hyper-sexuality, hypo-sexuality, exhibitionism and other sexual deviations have been reported. ${ }^{22} \mathrm{~A}$ very high suicide rate in HD has been noted, which may be the result of depression, but in some circumstances, may be a reflection of the patient's choice, particularly if he has previously witnessed the deterioration of other family members from HD. ${ }^{20,21}$

Cognitive dysfunction is invariably present in HD, and includes linguistic impairments, memory deficits, visuospatial problems, frontal lobe syndrome and the erosion of cognitive performance prior to the onset of the motor disorder. General productive linguistic abilities are preserved in HD patients. However, subtle linguistic deficits do exist and include reductions in number of words produced, syntactic complexity and phrase length as well as decreased articulatory agility, wordfinding difficulty and impairment in the comprehension and discrimination of prosody. ${ }^{23-25}$

Memory testing in HD patients reveals a unique deficit: while recall memory is usually severely impaired, recognition memory for the same material (especially verbal material) can appear almost normal. ${ }^{26-32}$ Remote memory, whether of the recent or remote past, is uniformly poor. ${ }^{33-35}$ It has been suggested that the memory deficit in HD may be a problem of retrieval of previously stored information, rather than a problem of encoding of information. ${ }^{36}$

HD patients demonstrate deficits in the processing of visuospatial information as demonstrated by lower performance IQ (PIQ) than verbal IQ (VIQ) on the WAIS-R, with impairments on such tests as Block Design, Object Assembly, Picture Arrangement and Picture Completion. ${ }^{37-39}$ Visuospatial impairments in HD patients have also been shown on the Mosaic Comparisons Test, the Rey-Osterriech Complex Figure and the Money Road Map. . $^{37-40}$

There is a striking similarity in symptoms between patients with HD and those who have sustained frontal lobe damage: like the latter, HD patients demonstrate problems in the planning, organizing, and sequencing of information as well as in cognitive flexibility and the formation of alternate strategies. These impairments are reflected in the Wisconsin Card Sorting Test, the Stroop Test, and the Tower of Hanoi puzzle and in the demonstration of movement sequences (e.g., use a key, sip through a straw). ${ }^{41-44}$

It has been suggested that cognitive and perceptual deficits may be present prior to the onset of the motor disorder. These findings remain somewhat controversial, with variable findings within the literature. ${ }^{45,46}$

Although the age of onset in HD is typically in the late thirties or early forties, there are two important variants. Juvenile $\mathrm{HD}$ is defined by disease onset prior to the age of twenty years. These individuals differ quite markedly from HD patients with older age of onset, as chorea is usually minimal or even completely absent. Severe, rapid mental deterioration, bradykinesia and rigidity are the predominant features with spasticity, cerebellar ataxia, myoclonus and epilepsy occurring frequently. By comparison, when symptom onset occurs in the sixth or seventh decades, chorea is the most prominent symptom. In these cases, the disease may have a very slow progression, and cognitive impairment may be minimal. ${ }^{2.3}$

\section{IMAGING}

Computerized axial tomography (CT) scanning can be useful in assessing striatal and cortical degeneration in HD. In the early stages of the disease, CT of the caudate is normal. With disease duration of five years or more, caudate atrophy is apparent, and disproportionately high in relation to cortical atrophy. ${ }^{47}$ 
Magnetic resonance imaging (MRI) does not provide improved definition of the caudate nuclei, but is useful in excluding other pathologies such as ischemic caudate lesions, HallervordenSpatz disease or multiple sclerosis. MRI has also been useful in demonstrating that in patients with HD characterized by rigidity, there is an increased signal intensity in the striatum that is not present in hyperkinetic HD patients. ${ }^{48}$

Positron emission tomography (PET) scanning in HD using ${ }^{18 F}$ deoxyglucose as a tracer typically reveals hypometabolism of the striatum, regardless of disease severity. Caudate metabolism correlates with cognitive function while putamen metabolism correlates with the onset of the motor disorder. ${ }^{12,49-51}$ In patients in the earliest stages of the disease, striatal hypometabolism found in PET scanning precedes tissue loss demonstrated through CT scanning, particularly in the caudate, with other areas demonstrating normal metabolism; later stage $\mathrm{HD}$ is also accompanied by cortical hypometabolism. ${ }^{52.53}$ Caudate hypometabolism has been reported to precede motor abnormalities $^{54}$ although likely only for a short period prior to the detection of clinical signs. Caudate nucleus hypometabolism should not be considered diagnostic for HD, as similar findings have been reported in other disorders such as neuroacanthocytosis and dentatorubropallidoluysian atrophy. ${ }^{55}$ [The findings of a previous paper ${ }^{56}$ describing a family with benign hereditary chorea with abnormal PET findings, most likely represent HD (M Hayden, personal communication).]

A recent study has suggested that benzodiazepine receptor density, using " ${ }^{11}$ flumazenil as a tracer, may provide a more sensitive measure of the progression of CNS dysfunction in early HD patients than ${ }^{185}$ deoxyglucose. With the latter tracer, the caudate, putamen and thalamus were all hypometabolic, but with ${ }^{11 C}$ flumazenil, only the caudate demonstrated decreased receptor density. ${ }^{57}$

\section{NEUROPATHOPHYSIOLOGY}

The study of the gross neuropathology of HD began in the late nineteenth and early twentieth centuries, most notably by Meynert, Golgi and Alzheimer. The best known gross neuropathology studies are those recent ones of Vonsattel and his colleagues. Through systematic study of a large sample of HD postmortem brains, Vonsattel et al..$^{58}$ were able to confirm and extend the observations of previous researchers, in finding that 1) the caudate undergoes greater degeneration than any other structure, and 2) the anteromedial aspects of the caudate are more affected than the lateral, posterior aspects. This study was also the first to establish a grading scale for progressive macroscopic degeneration in HD ranging from 0 (HD diagnosis, but no gross changes) through 4 (concave caudate/ventricular interface) ${ }^{58}$ Apart from striatal involvement, degenerative changes have also been noted in the cortex, globus pallidus, subthalamic nucleus, substantia nigra, nucleus accumbens and cerebellum. ${ }^{58-61}$

There are a number of neuronal types in the mammalian striatum; these include 1) the medium spiny neurons (which are the vast majority of the striatal neuronal population and form striatal efferents; associated transmitters include substance P, GABA, dynorphin and met-enkephalin), 2) the medium aspiny neurons (contained entirely within the striatum, do not form efferents; associated co-localized transmitters are somatostatin, neuropeptide $\mathrm{Y}$ and the biochemical marker NADPHdiaphorase/NO synthase), and 3 ) the large aspiny neurons (again contained entirely within the striatum and associated with acetylcholine). ${ }^{62-66}$

A common observation emerging from many early HD pathological studies was that small neurons were much more vulnerable to the degenerative disease process than larger neurons. This observation has been supported by recent investigations: it is well known that medium spiny neurons (those neurons that form the output from the striatum to other parts of the brain) undergo degeneration in HD while the medium aspiny neurons are spared. The loss of medium spiny neurons has been detailed in reductions of levels of or decreased immunoreactivity of associated neurotransmitters, including substance P, GABA, dynorphin and met-enkephalin..$^{67-73}$ Ellison et al. ${ }^{74}$ and Beal et al. ${ }^{75}$ have shown that reductions in GABA and glutamate levels correlate with pathological grade: reductions in GABA and glutamate are found in the caudate before other areas of the brain, and progressive transmitter reductions are associated with increasing pathological severity. In a comparison of choreic or rigid HD patients, Storey and $\mathrm{Beal}^{76}$ showed 1) a greater loss of GABA in the external division (GPe) than the internal division (GPi) of the globus pallidus as well as 2) increased GABA levels in the subthalamic nucleus and thalamus in choreic than rigid HD patients. Finally, preferential loss of striatal neurons projecting to the GPe and relative preservation of striatal neurons projecting to the GPi has been found in early and presymptomatic HD..$^{77,78}$

Similarly, the sparing of medium aspiny neurons in HD is reflected in preserved immunoreactivity as well as elevated (3-5 times) levels of somatostatin, neuropeptide $\mathrm{Y}$ and NADPH$\mathrm{d} / \mathrm{NO}$ synthase. This preservation is likely reflective of tissue shrinkage as well as neuronal sparing. ${ }^{79-81}$

With respect to the large aspiny neurons, cholineacetyltransferase (ChAT) levels are severely reduced in HD post-mortem brain, while staining for acetylcholinesterase (AChE) reveals preservation of cell bodies. This apparent discrepancy may be resolved on the basis of localization of each of these elements: AChE staining may be preserved due to its localization within cell bodies, while ChAT levels are reduced due to loss from axons and terminals. 82.83

Striatal dopamine levels (measured via tyrosine hydroxylase activity) are relatively preserved in HD tissue, likely a reflection of preservation of the dopaminergic projection from the substantia nigra to the striatum. ${ }^{84}$ Neuroanatomical and neurochemical studies of the cortex in HD have revealed loss of large pyramidal neurons but a preservation of local circuit neurons associated with GABA and neuropeptide $\mathrm{Y}^{85}$

The etiology of HD is unknown, but recent theories concerning pathogenesis have involved excitatory amino acids such as glutamate. In the attempt to elucidate the etiology of $\mathrm{HD}$, a number of animal models have been developed. Pathological and behavioural changes similar to HD can be caused by intrastriatal injection of such neurotoxins as quinolinic acid in rats and primates. ${ }^{86,87}$ Because quinolinic acid is a potent agonist of the N-methyl-D-aspartate (NMDA) subtype of glutamatergic receptors, it has been suggested that the degenerative process in HD is the product of an excitatory neurotoxin, ${ }^{88}$ possibly rending neurons bearing NMDA receptors particularly vulnerable to early damage. Such studies have led to clinical trials with drugs, 
such as lamotrigine (M Hayden, personal communication), which blocks the release of glutamate; in the case of HD, this mechanism would be directed towards reducing glutamate release from the corticostriatal projection. It has also recently been suggested that primary mitochondrial abnormalities in HD render neurons more vulnerable to excitotoxin-mediated damage. ${ }^{89}$ Along these lines, NMR spectroscopy has been used to demonstrate increased lactate levels in occipital cortex and striatum of symptomatic HD patients, suggestive of defective energy metabolism. ${ }^{90}$

\section{Genetics}

From its earliest descriptions, HD has been recognized as a hereditary disorder, transmitted in an autosomal dominant pattern of inheritance (children with an affected parent have a 50\% chance of inheriting the disease, regardless of the sex of the affected parent or offspring). Penetrance is complete, indicating that all individuals who have inherited the gene will develop symptoms, excluding those patients who die at an early age.

The clarification of the genetics of HD has been an exciting area of development in the past decade. In 1983, Wexler, Gusella and their colleagues demonstrated a marker for the HD gene on the short arm of chromosome $4,{ }^{91}$ a discovery which permitted predictive and prenatal testing for persons at risk. ${ }^{92.93}$ The development of the polymerase chain reaction (PCR) in the late 1980s facilitated the identification of the HD gene (now referred to as IT15), part of which is a triplet repeat (CAG) sequence located at the beginning of the transcribed portion of the gene. ${ }^{94}$ All individuals possess this repeat sequence; it is the number of triplet repeats that is significant. Normal individuals have 11-31 repeats while patients with HD have 38 or more repeats. ${ }^{95}$

Prior to the discovery of the HD gene, it had been noted that the age of onset of HD was related to the sex of the affected parent (i.e., genetic imprinting); most juvenile onset patients were found to have inherited the disease from their father, but if the disease was inherited from the mother, patients were more likely to have an age of onset similar to previously affected family members. ${ }^{6.8}$ Since the discovery of the gene this observation has been explained: the earlier the age of onset, the greater the number of triplet repeats for a given patient. Juvenile onset HD typically demonstrates the greatest number of repeat sequences (upwards of 55 repeats) while late onset HD shows the fewest number (38-43 repeats) ${ }^{96}$ It has been noted that, independent of age of onset, there is no association between repeat length and clinical symptoms at presentation. ${ }^{97}$ Further studies have shown that transmission of the gene through sperm results in an expansion of the number of repeats. ${ }^{98.99}$

The discovery of the HD gene has also permitted the identification of "sporadic" cases of HD. In some families, the number of triplet repeat sequences may be in the intermediate range (3438) and increase with successive generations (particularly with paternal transmission), finally resulting in the HD phenotype; this may account for cases of $\mathrm{HD}$, which in the past, may have appeared to be spontaneous mutations. ${ }^{100}$ The location and nature of the CAG repeat has been found to be identical in all families tested in a variety of populations. ${ }^{101}$

It is significant that up to $1 \%$ of individuals with clinical symptoms of HD may have a negative test result. ${ }^{95}$ In some families, a different genetic mutation may be responsible for the disorder. In others, a different disease process may be involved. It has recently been demonstrated that the genetic defect in dentatorubralpallidoluysian atrophy (DRPLA), a disease which includes choreoathetosis and dementia in its clinical symptomatology, is an expanded CAG repeat on the short arm of chromosome $12 .^{101-103}$

The messenger RNA transcribed from the HD gene is found in all organs, although it may be present in higher levels in the brain. The translated protein has not been characterized but appears to be different from any recognizable protein to date; it has tentatively been called "huntingtin". ${ }^{98}$ The relationship between the protein and the pathogenesis of HD remains to be determined.

\section{Differential Diagnosis}

In an individual with a clear family history of HD and an autosomal dominant pattern of inheritance, the diagnosis of HD may not be difficult, although consideration of other possible causes of dementia and chorea is important. In the older patient, neurodegenerative conditions such as Alzheimer's Disease, olivopontocerebellar atrophy (OPCA) and multiinfarct dementia may mimic symptoms of HD. In younger patients, conditions such as Hallervorden-Spatz Disease and Wilson's Disease may cause a choreiform movement disorder and/or bradykinesia in the early stages.

One of the most important categories in the differential diagnosis is that of drug-induced chorea. For example, tardive dyskinesia can cause diagnostic confusion, particularly in the situation where an individual at risk for HD is started on neuroleptics for psychiatric problems. Other commonly used drugs such as phenytoin, lithium and digoxin have been reported to cause chorea (see Table 1 for a complete list of causes of chorea).

Prior to the discovery of the HD gene in 1993, confirmation of a diagnosis of HD required intensive investigation of all causes of chorea. With the development of an accurate DNA test, patients with typical symptoms but absent family history should have this test performed before all others. If the trinucleotide sequences are within the normal range, a full workup is then required, including a CT/MRI scan, EEG, nerve conduction studies and bloodwork including CBC, ESR and smear for acanthocytes, as well as thyroid function tests, electrolytes, calcium, serum copper and ceruloplasmin, ANA, liver function tests, CPK, creatinine, VDRL and HIV. Post-mortem neuropathological analyses of the brain remains extremely useful, since clinical false positives and negatives occur in up to $15 \%$ of cases ${ }^{104}$ (although this error margin should decrease with the availability of DNA testing).

\section{MANAGEMENT}

Although there is no definitive treatment for HD, medical therapy and psychosocial intervention through a multi-disciplinary approach will help both the affected individual and family members cope with the disease.

Medical therapy revolves around treating the movement disorder and psychiatric problems. With respect to chorea, neuroleptics are useful in suppressing abnormal movements; 
Table 1. Differential diagnosis of chorea.

\author{
A. Genetic \\ Huntington's Disease \\ benign hereditary chorea \\ neuroacanthocytosis \\ familial paroxysmal kinesogenic choreoathetosis \\ familial paroxysmal dystonic choreoathetosis \\ late onset Pelizeus-Merzbacher Disease \\ pseudo/pseudopseudo hypoparathyroidism \\ Niemann-Pick disease \\ dentato-rubro-pallido-luysian atrophy \\ neuronal lipofuscinosis \\ Wilson's disease \\ Lesch-Nyhan disease \\ Hallervorden-Spatz Disease \\ mitochondrial cytopathy
}

B. Degenerative: Alzheimer's Disease; Pick's Disease; olivo-pontocerebellar atrophy

\section{Trauma}

D. Neoplasia

E. Vascular: infarct; arterio-venous malformation

F. Immune: Sydenham's chorea; chorea gravidarum; systemic lupus erythematosus; periarteritis nodosa; Behçet's disease; multiple sclerosis

G. Infectious: diphtheria, neurosyphilis, tuberculosis; Lyme disease; Legionnaire's disease; encephalitis; AIDS

H. Metabolic: hypo/hypernatremia; hypocalcemia; hypo/hyperglycemia; hyperthyroidism; hepatocerebral degeneration; renal failure; thiamine deficiency; niacin deficiency

I. Toxins: alcohol; carbon monoxide; mercury; manganese

J. Drugs: neuroleptics; anti-parkinsonian medications; anticonvulsants; noradrenergic stimulants; steroids; opiates; tricyclic antidepressants; lithium; digoxin

there is no evidence that one particular drug is better than another. Traditionally, haloperidol has been the drug of choice. It has been shown that low doses (up to $10 \mathrm{mg} /$ day) are as effective as higher doses, and cause fewer side effects. ${ }^{105} \mathrm{~A}$ more useful drug, particularly with milder chorea, may be tetrabenazine, a presynaptic dopamine depleting agent. It has not been released for general use, but is available in most Movement Disorder Clinics. The most significant side effects are sedation and depression; the main advantage is that there is little risk for developing tardive dyskinesia.

Urinary incontinence, a frequent problem in advanced HD, may respond to oxybutinin, or low dose tricyclic antidepressants at bedtime. Incontinence pads can be used by the patient in later stages. In the case of incontinence, infection always needs to be ruled out.

Over $40 \%$ of patients with HD experience depression, particularly in the early stages of the disease. ${ }^{3}$ This may be either reactive depression or an intrinsic component of the disease, and usually will respond to tricyclic antidepressants. The selective serotonin reuptake inhibitors (SSRIs; e.g., fluoxetine, sertraline, paroxetine) may prove useful, although no formal trials for HD patients are available. The risk of suicide is significant in HD patients and appropriate questions should be asked in all patients to determine suicidal intent. Psychiatric symptoms, such as anti-social behaviour, may require neuroleptics and psychiatric intervention.

Ongoing supportive psychotherapy is frequently necessary, not only for the affected individuals, but for all family members. It will allow the affected individual to deal with development of disability, loss of career and independence. As the disorder progresses, the patient may become increasingly irrational, irritable and forgetful. Caregivers experience increased stress in dealing with the patient and their increased demands. Marriage and family breakup are not uncommon. ${ }^{3}$ Counselling is sometimes necessary to allay the guilt that family members associate with placing a loved one in a nursing home.

Support services from social welfare and Home Care will aid the caregiver in keeping the patient at home as long as possible. Physiotherapy and occupational therapy will keep the patient mobile in a safe environment. Dieticians ensure that the patient receives appropriate high calorie nutrition. Speech therapy maintains communicative abilities and deals with problems of dysphagia. Feeding gastrostomy may become necessary in later stages. As the disorder progresses, institutional care is required. Legal aspects of care are also important to discuss with the patient and family (e.g., guardianship and trusteeship) so that the individual remains well cared for, both medically and financially.

Genetic counselling at a Medical Genetics Clinic should be arranged in all families with HD, as most at risk individuals feel that they benefit from this knowledge. Some may wish to consider options that would prevent passing on the disorder such as sterilization, in vitro fertilization or presymptomatic testing.

The Huntington Society of Canada, a lay support group, is very helpful in providing information and support to families affected by HD.

\section{Predictive Testing}

The identification of the gene marker has permitted presymptomatic testing for persons at risk since 1987. Such a test inevitably raises ethical issues but a survey of at-risk individuals showed that the majority felt that presymptomatic testing should be available so that informed decisions concerning careers, retirement and childbearing could be made as young adults. ${ }^{106}$ One drawback of the previously available gene marker test (the indirect test) was that it could only be performed when DNA from a number of affected and unaffected family members was available. Undetected recombination events were a source of error, resulting in test accuracy of approximately $95 \%$.

The introduction of presymptomatic testing in 1987 in Canada was guided by a National Research Protocol which involved several sessions of pre-test and post-test counselling to ensure that individuals understood the possible and varied ramifications of testing. ${ }^{107}$ In particular, counselling sessions were felt to be necessary to provide ongoing support as psychological problems could occur in individuals receiving either an increased or decreased risk result. ${ }^{108}{ }^{109}$ Most individuals who have undergone testing have indicated that the counselling experience was a positive one, regardless of the outcome. Presymptomatic and prenatal testing became available in 1992 as a service in some major centres.

The identification of the HD gene has permitted a more accurate test for persons at risk (i.e., the direct test). Use of PCR technology means that the tests can be done quickly and accurately 
using the patient's DNA and DNA from other relatives is no longer required. Individuals with chorea of unknown etiology or absent family history are also able to receive an accurate diagnosis regarding HD status. Pre- and post-test counselling is strongly recommended for all participants to allow the individual to make an informed decision and provide ongoing support. The long term outcome of this type of testing is unknown, and information is still being gathered under a research protocol in some Canadian centres.

Presymptomatic testing needs to be carried out only under rigid guidelines. First, it should only be performed at the request of the patient. Other family members, physicians, insurance companies and lawyers should not be permitted to request testing under any circumstatnces. Second, the test result should only be released to the patient. If the result is to be released to another party, written consent is required from the patient. Third, it is presently inappropriate to test children under the age of majority because this knowledge may have significant negative repercussions in raising the child. ${ }^{110}$ In fact, presymptomatic testing of minors is not available in Canada.

HD is a progressive neurodegenerative disease for which there is no cure. However, much can be done to help the patient medically and to provide ongoing support to the patient and family. The identification of the HD gene has provided the impetus for much new research and the hope that the isolation of the genetic defect, identification of the etiology and development of an effective treatment, will soon be realized.

\section{REFERENCES}

1. Huntington G. On Chorea. Med Surg Rep 1872; 26: 317-321.

2. Hayden MR. Huntington's Disease. Berlin: Springer-Verlag, 1981: $1-12$.

3. Harper PS. Huntington's Disease. London: Saunders, 1991: 1-15.

4. Folstein SE, Chase GA, Wahl WE, et al. Huntington's disease in Maryland: clinical aspects of racial variation. Am J Hum Genet 1987; 41: 168-179.

5. Shokeir MHK. Investigations on Huntington's disease in the Canadian prairies. I Prevalence. Clin Genet 1975; 7: 345-348.

6. Newcombe RG, Walker DA, Harper PS. Factors influencing age at onset and duration of survival in Huntington's chorea. Ann Hum Genet 1981; 45: 387-396.

7. Bird ED, Iversen LL. A sex related factor in the inheritance of Huntington's chorea. Ann Hum Genet 1974; 37: 255-260.

8. Myers RH, Goldman D, Bird ED, Sax DS, Merril CR, et al. Maternal transmission in Huntington's Disease. Lancet 1988; 2: 208-210.

9. Young AB, Shoulson I, Penney JB, et al. Huntington's Disease in Venezuela: neurological features and functional decline. Neurology 1986; 36: 244-249.

10. Penney JB, Young AB, Shoulson I, et al. Huntington's Disease in Venezuela: seven years of followup on symptomatic and asymptomatic individuals. Mov Disord 1990; 5: 93-99.

11. Koller WC, Trimble J. The gait abnormality of Huntington's Disease. Neurology 1985; 35: 1450-1454.

12. Young AB, Penney JB, Starosta-Rubinstein S, Markel DS, Berent $S$, et al. PET Scan investigations of Huntington's Disease: cerebral metabolic correlates of neurological features and functional decline. Ann Neurol 1986; 20: 296-303.

13. Hefter H, Homberg V, Lange HW, Freund H-J. Impairment of rapid movement in Huntington's Disease. Brain 1987; 110: 585612.

14. Folstein SE, Leigh J, Parhad IM, Folstein MF. The diagnosis of Huntington's Disease. Neurology 1986; 36: 1279-1283.

15. Thompson PD, Berardelli A, Rothwell JC, Day BL, Dick JPR, et al. The coexistence of bradykinesia and chorea in Huntington's Disease and its implications for theories of basal ganglia control of movement. Brain 1988; 111:223-244.
16. Lasker AG, Zee DS, Hain TC, Folstein SE, Singer HS. Saccades in Huntington's Disease: initiation defects and distractability. Neurology 1987; 37: 364-370.

17. Tian JR, Zee DS, Lasker AG, Folstein SE. Saccades in Huntington's Disease. Predictive tracking and interaction between release of fixation and initiation of saccades. Neurology 1991; 41: 875-881.

18. Sanberg PRF, Fibiger MC, Mark RF. Body weight and dietary factors in Huntington's disease patients compared with matched controls. Med J Austr 1981; 1:407-409.

19. Walker DP, Harper PS, Wells CEC, et al. Huntington's disease in South Wales: a genetic and epidemiological study. Clin Genet 1981; 19: 213-221

20. Folstein SE, Abbott MH, Chase GA, Jensen BA, Folstein MF. The association of affective disorder with Huntington's Disease in a case series and in families. Psychol Med 1983a; 13: 537-542.

21. Folstein SE, Franz ML, Jensen BA, Chase GA, Folstein MF. Conduct disorder and affective disorder among the offspring of patients with Huntington's Disease. Psychol Med 1983b; 13: 4552.

22. Dewhurst K, Oliver JE, McKnight AL. Socio-psychiatric consequences of Huntington's disease. Br J Psychol 1970; 16: 255258.

23. Ludlow CL, Connor NP, Bassich CJ. Speech timing in Parkinson's and Huntington's Disease. Brain Lang 1987; 32: 195.214

24. Illes J. Neurolinguistic features of spontaneous language production dissociate three forms of neurodegenerative diseases: Alzheimer's, Huntington's and Parkinson's. Brain Lang 1989; 37: 628-642.

25. Speedie LJ, Brake N, Folstein SE, Bowers D, Heilman KM. Comprehension of prosody in Huntington's Disease. J Neurol Neurosurg Psychiatry 1990; 53: 607-610.

26. Massman PJ, Delis DC, Butters N, Levin BE, Salmon DP. Are all subcortical dementias alike? Verbal learning and memory in Parkinson's and Huntington's Disease patients. J Clin Exp Neuropsychol 1990; 12(5): 729-744.

27. Hodges JR, Salmon DP, Butters N. Differential impairment of semantic and episodic memory in Alzheimer's and Huntington's diseases: a controlled prospective study. J Neurol Neurosurg Psychiatry 1990; 53: 1089-1095.

28. Butters N, Wolfe J, Martone M, Granholm E, Cermak L. Memory disorders associated with Huntington's disease: verbal recall, verbal recognition and procedural memory. Neuropsychology $1985 ; 23(6): 729-743$.

29. Butters N, Wolfe J, Granholm E, Martone M. An assessment of verbal recall recognition and fluency abilities in patients with Huntington's Disease. Cortex 1986; 22: 11-32.

30. Butters N, Granholm E, Salmon DP, Grant I, Wolfe J. Episodic and semantic memory: a comparison of amnesic and demented patients. J Clin Exp Neuropsychol 1987; 9: 479-497.

31. Granholm E, Butters N. Associative encoding and retrieval in Alzheimer's and Huntington's Disease. $\mathrm{Br} \mathrm{Cog}$ 1988; 7 : 335347.

32. Heindel WC, Salmon DP, Butters N. Pictorial priming and cued recall in Alzheimer's and Huntington's Disease. Br Cog 1990; 13: 282-295.

33. Albert MS, Butters N, Brandt J. Patterns of remote memory in amnesic and demented patients. Arch Neurol 1981; 38: 495-500.

34. Beatty WW. Remote memory for visuospatial information in patients with Huntington's Disease. Psychobiology 1989; 17: 431-434.

35. Beatty WW, Salmon DP, Butters N, Heindel WC, Granholm EL. Retrograde amnesia in patients with Alzheimer's or Huntington's Disease. Neurobiol Aging 1988; 9: 181-186.

36. Brandt J, Butters N. The neuropsychology of Huntington's Disease. Trends Neurosci 1986; 9: 118-120.

37. Fedio P, Cox CS, Neophytides A, Canal-Frederick G, Chase TN. Neuropsychological profile of Huntington's Disease: patients and those at risk. Adv Neurol 1979; 23: 239-255.

38. Sax DS, O’Donnell B, Menzer L, Montgomery K, Kayne HL. Computed tomographic, neurologic, and neuropsychological correlates of Huntington's Disease. Int J Neurosci 1983; 18: 21 36. 
39. Moses JA, Golden CJ, Berger PA, Wisniewski AM. Early, middle and late stage Huntington's Disease as measured by the LuriaNebraska neuropsychological battery. Int J Neurosci 1981; 14: 95-100.

40. Brouwers P, Cox C, Martin A, Chase T, Fedio P. Differential perceptual-spatial impairment in Huntington's and Alzheimer's dementias. Arch Neurol 1984; 41: 1073-1076.

41. Caine ED, Fisher JH. Dementia in Huntington's Disease. Hand Clin Neurol 1985; 46: 305-310.

42. Josiassen RC, Curry LM, Mancall EL. Development of neuropsychological deficits in Huntington's Disease. Arch Neurol 1983; 40: 791-796.

43. Knopman D, Nissen MJ. Procedural learning is impaired in Huntington's Disease: evidence from the serial reaction time test. Neuropsychology 1991; 29(3): 245-254.

44. Shelton PA, Knopman DS. Ideomotor apraxia in Huntington's Disease. Arch Neurol 1991; 48: 35-41.

45. Lyle OE, Gottesman II. Premorbid psychometric indicators of the gene for Huntington's Disease. J Consult Clin Psychol 1977; 45: $1011-1022$.

46. Jason GW, Pajurkova EM, Suchowersky O, Hewitt J, Hilbert C, et al. Presymptomatic neuropsychological impairment in Huntington's Disease. Arch Neurol 1988; 45: 769-773.

47. Barr AN, Heinze WJ, Dobben GD. Bicaudate index in computerized tomography of HD and cerebral atrophy. Neurology 1978; 28: $1196-1200$

48. Savoiardo M, Strada L, Oliva D, et al. Abnormal MRI signal in the rigid form of Huntington's Disease. J Neurol Neurosurg Psychiatry $1991 ; 54: 888-891$.

49. Hayden MR, Martin WRW, Stoessl AJ, et al. Positron emission tomography in the early diagnosis of Huntington's disease. Neurology 1986; 36: 888-894.

50. Hayden MR, Hewitt HJ, Martin WRW, et al. Studies in persons at risk for Huntington's disease. N Engl J Med 1987; 317: 382383.

51. Garnett ES, Firnau G, Nahmias C, Carbotte R, Bartolucci G. Reduced striatal glucose consumption and prolonged reaction time and early features in Huntington's Disease. J Neurol Sci 1984; 65: 231-237.

52. Kuwert T, Lange HW, Langen K-J, Herzog H, Aulich A, et al. Cortical and subcortical glucose consumption measured by PET in patients with Huntington's Disease. Brain 1990; 113: 1405-1423.

53. Martin WR, Clark C, Ammann W, Stoessl AJ, Shtybel W, et al. Cortical glucose metabolism in Huntington's Disease. Neurology 1992; 42: 223-229.

54. Hayden MR, Hewitt J, Stoessl AJ, Clark C, Ammann W, et al. The combined use of positron emission tomography and DNA polymorphisms for preclinical detection of Huntington's Disease. Neurology 1985; 37: 1441-1447.

55. Hosokawa S, Ichiya Y, Kuwabara Y, Ayabe Z, Mitsuo K, et al. Positron emission tomography in cases of chorea with different underlying diseases. J Neurol Neurosurg Psychiatry 1987; 50: 1284-1287.

56. Suchowersky O, Hayden MR, Martin WRW, et al. Cerebral metabolism of glucose in benign hereditary chorea. Mov Disord 1986; 1: 33-44.

57. Holthoff VA, Koeppe RA, Frey KA, Penney JB, Markel DS, et al. Positron emission tomography measures of benzodiazepine receptors in Huntington's Disease. Ann Neurol 1993; 34: 76-81.

58. Vonsattel J-P, Myers RH, Stevens TJ, Ferrante RJ, Bird ED, et al. Neuropathological classification of Huntington's Disease. J Neuropathol Exp Neurol 1985; 44(6): 559-577.

59. de la Monte SM, Vonsattel J-P, Hedley-Whyte ET, Ulcickas M, Richardson EP. Global loss of cerebral cortex and white matter in Huntington's Disease. J Neuropathol Exp Neurol 1987; 46: 342.

60. de la Monte SM, Vonsattel J-P, Richardson EP. Morphometric demonstration of atrophic changes in the cerebral cortex, white matter and neostriatum in Huntington's Disease. J Neuropathol Exp Neurol 1988; 47(5): 516-525.

61. Mann DMA, Olivier R, Snowden JS. The topographic distribution of brain atrophy in Huntington's Disease and progressive supranuclear palsy. Acta Neuropathol 1993; 85: 553-559.
62. DiFiglia M, Pasik T, Pasik P. Ultrastructure of Golgi-impregnated and gold-toned spiny and aspiny neurons in the monkey neostriatum. J Neurocytol 1980; 8: 471-492.

63. Graveland GA, Williams RS, DiFiglia M. Evidence for degenerative and regenerative changes in neostriatal spiny neurons in Huntington's Disease. Science 1985; 227: 770-773.

64. Graybiel AM, Ragsdale CW. Biochemical anatomy of the striatum. In: Emson PC, ed. Chemical Neuroanatomy. New York: Raven Press, 1983.

65. Niewenhuys R. Chemoarchitecture of the Human Brain. Berlin: Springer-Verlag, 1988.

66. Vincent SR. Nitric oxide: a radical neurotransmitter in the central nervous system. Progr Neurobiol 1994; 42: 129-160.

67. Perry TL, Hansen S, Kloster M. Huntington's chorea. Deficiency of gamma-amino butyric acid in brain. N Engl J Med 1973; 288(7): 377-342.

68. Bird ED, MacKay AVP, Rayner CN, Iversen LL. Reduced glutamic acid-decarboxylase activity of post-mortem brain in Huntington's Chorea. Lancet 1973; 2: 1090-1092.

69. Kanazawa I, Bird ED, Gale JS, Iversen LL, Jessell TM, et al. Substance P: Decrease in substantia nigra and globus pallidus in Huntington's Disease. Adv Neurol 1985; 23: 495-504.

70. Marshall PE, Landis DMD, Zalneraitis EL. Studies of substance P and leu-enkephalin in Huntington's Disease. Br Res 1983; 289: 11-26.

71. Grafe MR, Forno LS, Eng LF. Immunocytochemical studies of substance $P$ and met-enkephalin in the basal ganglia and substantia nigra in Huntington's, Parkinson's and Alzheimer's Diseases. J Neuropathol Exp Neurol 1985; 44(1): 47-59.

72. Emson PC, Arregui A, Clement-Jones V, Sandberg BEB, Rossor M. Regional distribution of methionine-enkephalin and substance $P$ immunoreactivity in normal human brain and Huntington's Disease. Brain Res 1980; 199: 147-160.

73. Seizinger BR, Liebisch DC, Kish SH, Arendt RJ, Hornykiewicz O, et al. Opioid peptides in HD: alterations in prodynorphin and proenkephalin system. Brain Res 1986; 378; 405-408.

74. Ellison DW, Beal MF, Mazurek MF, Malloy JR, Bird ED, et al. Amino acid neurotransmitter abnormalities in Huntington's Disease and the quinolinic acid animal model of Huntington's Disease. Brain 1987; 110: 1657-1673.

75. Beal MF, Ellison DW, Mazurek MF, Swartz KJ, Malloy JR, et al. A detailed examination of susbtance $P$ in pathologically graded cases of Huntington's Disease. J Neurol Sci 1988; 84: $51-61$.

76. Storey E, Beal MF. Neurochemical substrates of rigidity and chorea in HD. Brain 1993; 116: 1201-1223.

77. Albin RL, Young AB, Penney JB, et al: Abnormalities of striatal projection neurones and $\mathrm{N}$-methyl-D-aspartate receptors in presymptomatic Huntington's disease. N Engl J Med 1990; 322: 1293-1298.

78. Albin RL, Reiner A, Anderson KD, et al. Preferential loss of striato-external pallidal projection neurons in presymptomatic Huntington's Disease. Ann Neurol 1992; 31: 425-430.

79. Dawbarn D, De Quidt ME, Emson PC. Survival of basal ganglia neuropeptide Y-somatostatin neurons in Huntington's Disease. Brain Res 1985; 340: 251-260.

80. Ferrante RJ, Kowall NW, Beal MF, Richardson EP, Bird ED, et al. Selective sparing of a class of striatal neurons in HD. Science 1985; 230: $561-563$.

81. Ferrante RJ, Kowall NW, Martin JB, Richardson EP. Characteristics of a selectively spared subset of neurons in HD. J Neuropathol Exp Neurol 1985; 44: 1325.

82. Bird ED. Chemical pathology of Huntington's Disease. Ann Rev Pharmacol Toxicol 1980; 20: 533-551.

83. Ferrante RJ, Kowall NW, Richardson EP Jr, et al. Topography of enkephalin, substance $P$ and acetylcholinesterase in Huntington's Disease striatum. Neurosci Lett 1986; 71: 283-288.

84. Kish SJ, Shannak K, Hornkiewicz O. Elevated serotonin and reduced dopamine in subregionally divided Huntington's Disease striatum. Ann Neurol 1987; 22: 386-389.

85. Cudkowicz M, Kowall NW. Degeneration of pyramidal projection neurons in Huntington's Disease. Ann Neurol 1990; 27: 200204. 
86. Beal MF, Kowall NW, Ellison DW, Mazurek MF, Swartz KJ, et al. Replications of the neurochemical characteristics of Huntington's Disease by quinolinic acid. Nature 1986; 321: 168171.

87. Brownell A-L, Hantraye P, Wullner U, Hamberg L, Shoup T, et al. PET- and MRI-Based assessment of glucose utilization, dopamine receptor binding and hemodynamic changes after lesions to the caudate-putamen in primates. Exp Neurol 1994; 125: 41-51.

88. Cross AJ, Slater P, Reynolds GP. Reduced high affinity glutamate uptake sites in the brains of patients with Huntington's disease. Neurosci Lett 1986; 67:198-202.

89. Beal MF, Hyman BT, Koroshetz W. Do defects in mitochondrial energy metabolism underlie the pathology of degenerative diseases. Trends Neurosci 1993; 16(6): 125-131.

90. Jenkins BG, Koroshetz WJ, Beal MF, Rosen BR. Evidence for impairment of energy metabolism in vivo in Huntington's Disease using localized 'H-NMR spectroscopy. Neurology 1993; 43: 2689-2695.

91. Gusella JF, Wexler NS, Conneally PM, Naylor SL, Anderson MA, et al. A polymorphic DNA marker genetically linked to Huntington's Disease. Nature 1983; 306: 234-238.

92. Hayden MR, Kastelein JJ, Wilson RD, Hilbert C, Hewitt J, et al. First trimester prenatal diagnosis for Huntington's Disease with DNA probes. Lancet 1987; 1284-1285.

93. Evers-Kieboom G, Siverts A, Cassiman JJ, Van der Berghe H. The motivation of at-risk individuals and their partners in deciding for or against predictive testing for Huntington's disease. Clin Genet 1989; 35: 29-40.

94. Huntington's Disease Collaborative Research Group. A novel gene containing a trinucleotide repeat that is expanded and unstable on Huntington's Disease chromosomes. Cell 1993; 72: 971-983.

95. MacMillan JC, Snell RG, Tyler A, Houlihan GD, Fenton I, et al. Molecular analysis and clinical correlations of the Huntington's Disease mutation. Lancet 1993; 342: 954-958.

96. Duyao M, Ambrose CM, Myers RM, et al. Trinucleotide repeat length instability and age of onset in Huntington's Disease. Nature Genetics 1993; 4: 387-392.
97. Andrew SE, Goldberg YP, Kremer B, et al. The relationship between trinucleotide (CAG) repeat length and clinical features of Huntington's Disease. Nature Genetics 1993; 4: 398-403.

98. Goldberg YP, Kremer B, Andrew, et al. Molecular analysis of new mutations for Huntington's Disease: intermediate alleles and sex of origin effects. Nature Genetics 1993; 5: 174-179.

99. MacDonald ME, Barnes G, Srinidhi J, et al. Gametic but not somatic instability of CAG repeat length in Huntington's Disease. J Med Genet 1993; 30: 982-986.

100. Myers RH, MacDonald ME, Koroshetz WJ, Duyao MP, Ambrose $\mathrm{CM}$, et al. De novo expansion of (CAG)n repeat in sporadic Huntington's Disease. Nature Genetics 1993; 5: 168-173.

101. Andrew SE, Goldber YP, Kremer B, et al. Huntington Disease without CAG expansion: phenocopies or errors in assignment? Am J Hum Genet 1994; 54: 852-863.

102. Nagafuchi $S$, et al. Dentatorubral and pallidoluysian atrophy expansion of an unstable CAG trinucleotide on chromosome 12p. Nature Genetics 1994; 6: 14-18.

103. Koide R, et al. Unstable expansion of CAG repeat in hereditary DRPLA. Nature Genetics 1994; 6: 9-13.

104. Folstein SE. Huntington's Disease: A Disorder of Families. Baltimore: Johns Hopkins University Press, 1989.

105. Barr AN, Fischer JH, Koller WC, et al. Serum haloperidol concentration and choreiform movements in Huntington's disease. Neurology 1988; 38: 84-88.

106. Mastromauro C, Myers RH, Berkman B. Attitudes toward presymptomatic testing in Huntington's Disease. Am J Med Genet 1987; 26: 271-282.

107. Fox S, Bloch M, Fahy M, Hayden MR. Predictive testing for Huntington's Disease. I. Description of a pilot project in British Columbia. Am J Med Genet 1989; 32: 21 1-216.

108. Huggins $M$, Bloch $M$, Wiggins S, et al. Predictive testing of Huntington's disease in Canada: Adverse effects and unexpected results in those receiving a decreased risk. Am J Med Genet 1992; 42: 508-515.

109. Wiggins S, Whyte P, Huggins M, et al. The psychological consequences of predictive testing for Huntington's disease. $N$ Engl J Med 1992; 327: 1401-1405.

110. World Federation of Neurology Research Group on Huntington's Disease. Ethical issues policy statement on Huntington's Disease molecular genetics predictive testing. J Med Genet 1990; 27: 34-38. 